\title{
OPTIMALISASI POTENSI KEWIRAUSAHAAN DAN PEMASARAN PRODUK UNGGULAN DESA TAMIYANG
}

\author{
Henky Lisan Suwarno${ }^{1}$, Yolla Margaretha ${ }^{2}$, Asni Harianti ${ }^{3}$, Nur $^{4}$, Maya Malinda ${ }^{5}$, \\ Chandra Kuswoyo ${ }^{6}$, Rully Arlan Tjahjadi ${ }^{7}$, Allen Kristiawan ${ }^{8}$, \\ Olivia Vania Olius ${ }^{9}$, dan Meryana ${ }^{10}$
}

\author{
${ }^{1}$ Program Studi Manajemen, Universitas Kristen Maranatha Bandung \\ Surel: henky.1s@eco.maranatha.edu \\ ${ }^{2}$ Program Studi Manajemen, Universitas Kristen Maranatha Bandung \\ Surel: yolla.margaretha@ eco.maranatha.edu \\ ${ }^{3}$ Program Studi Manajemen, Universitas Kristen Maranatha Bandung \\ Surel: asni.harianti@eco.maranatha.edu \\ ${ }^{4}$ Program Studi Manajemen, Universitas Kristen Maranatha Bandung \\ Surel:nur@eco.maranatha.edu \\ ${ }^{5}$ Program Studi Manajemen, Universitas Kristen Maranatha Bandung \\ Surel: maya.malinda@eco.maranatha.edu \\ ${ }^{6}$ Program Studi Manajemen, Universitas Kristen Maranatha Bandung \\ Surel: chandra.kuswoyo@eco.maranatha.edu \\ ${ }^{7}$ Program Studi Manajemen, Universitas Kristen Maranatha Bandung \\ Surel: rully.arlan@eco.maranatha.edu \\ ${ }^{8}$ Program Studi Manajemen, Universitas Kristen Maranatha Bandung \\ Surel: allen.kristiawan@eco.maranatha.edu \\ ${ }^{9}$ Program Studi Manajemen, Universitas Kristen Maranatha Bandung \\ Surel: olivia_vania16@yahoo.com \\ ${ }^{10}$ Program Studi Manajemen, Universitas Kristen Maranatha Bandung \\ Surel: meryana1999@gmail.com
}

\begin{abstract}
Tamiyang is a village that has abundant agricultural and plantation products, one of which is mango. Besides that, there are also a lot of raw materials available in the village. The two sources of raw materials available in nature, both mango and wood, have not been used optimally to add value, especially to improve the community's economy. The community service activities discuss the optimization of entrepreneurial potential and marketing for Tamiyang's superior products. This activity was carried out by means of a Focus Group Discussion and Training. Through this activity, it is hoped that it will have an impact on improving the economy of the community itself. In particular, at this community service, we are helping Tamiyang people to make a product that is unique, namely Si Mayang. Mayang stands for Mangga Tamiyang, which in Tamiyang Village is indeed very abundant in the yields of mangoes. In addition, we also monitor the continuation of the manufacture and promotion of coffin products that have been made before. Through this community service activity, Tamiyang Village has a product in the form of Manisan Si Mayang which is the hallmark of the area. In addition, the initial stage of optimizing coffin products produced by the community was also achieved, in the form of a design improvement plan and a proper coffin pricing determination. Keywords: Optimization, entrepreneurial and marketing potential, superior products
\end{abstract}

\footnotetext{
ABSTRAK

Tamiyang merupakan desa yang memiliki hasil pertanian dan perkebunan yang melimpah, salah satu hasil perkebunan yang dihasilkan adalah mangga. Selain itu juga banyak sekali bahan baku yang tersedia di desa tersebut. Kedua sumber bahan baku yang tersedia di alam, baik itu mangga dan kayu belum dimanfaatkan secara optimal untuk menambah nilai, khususnya untuk meningkatkan perekonomian masyarakat. Adapun kegiatan pengabdian masyarakatnya membahas optimalisasi potensi kewirausahaan dan pemasaran bagi produk unggulan Tamiyang. Kegiatan ini dilakukan dengan Focus Group Discussion dan Pelatihan. Melalui kegiatan ini diharapkan nantinya akan berdampak pada peningkatan perekonomian masyarakat itu sendiri. Secara khusus, pada pengabdian kepada
} 
masyarakat kali ini kami membantu masyarakat Tamiyang membuat produk yang menjadi keunikannya, yaitu Manisan Si Mayang. Mayang ini kepanjangan dari Mangga Tamiyang, yang mana di Desa Tamiyang ini memang sangat berlimpah sekali hasil panen dari buah mangga. Selain itu kami juga melakukan pemantauan mengenai kelanjutan dari pembuatan dan promosi produk peti mati yang sudah pernah dibuat oleh sebelumnya. Melalui kegiatan pengabdian masyarakat ini, Desa Tamiyang memiliki produk berupa Manisan Si Mayang yang menjadi ciri khas daerah tersebut. Selain itu juga dicapai tahap awal dari optimalisasi produk peti mati yang diproduksi oleh masyarakat, berupa rencana perbaikan desain dan penentuan harga peti mati yang layak.

Kata kunci: Optimalisasi, potensi kewirausahaan dan pemasaran, produk unggulan

\section{PENDAHULUAN}

Dalam Undang-Undang No. 12 Tahun 2012, disebutkan bahwa kewajiban Tridharma Perguruan Tinggi adalah kewajiban Perguruan Tinggi untuk menyelenggarakan Pendidikan, Penelitian dan Pengabdian Masyarakat. Menanggapi hal ini, universitas sebagai salah satu lembaga pendidikan mengemban tanggung jawab untuk dapat mendidik dan menghasilkan lulusan mahasiswa yang tidak hanya kompeten dalam bidang ilmu namun juga kompeten secara sosial. Mahasiswa sebagai generasi muda penerus bangsa yang akan mewarisi nilai-nilai dan budaya bangsa harus memiliki kompetensi-kompetensi ilmu dan sosial yang memadai untuk dapat memajukan bangsa dan negara. Hal tersebut dapat didukung oleh rasa cinta terhadap nilai-nilai dan kebudayaan bangsa yang harus tetap dijaga dan diwariskan pada setiap generasi sehingga jati diri negara Indonesia dapat dilihat dan diakui oleh negara lain. Tentunya apabila hanya dibekali dengan ilmu secara teori saja, mahasiswa akan sulit mencapai tujuan pendidikan yang sebenarnya. Dosen dan Mahasiswa membutuhkan praktik nyata secara langsung dalam kehidupan bermasyarakat agar mereka dapat memperoleh pemahaman yang lebih utuh dan mendalam. Menyadari hal tersebut dan untuk menjalankan pengabdian masyarakat sesuai Tri Dharma Perguruan Tinggi, maka Universitas Kristen Maranatha melalui kerjasama antara KBK (Kelompok Bidang Keahlian) Kewirausahaan dan KBK Kewirausahaan Program Studi Manajemen ingin menyelenggarakan kegiatan penelitian dan pengabdian masyarakat bersama Gereja Kristen Pasundan (GKP) Desa TAMIYANG, Indramayu. Adapun tempat yang dituju adalah Gereja Kristen Pasundan di Desa TAMIYANG berada di daerah Indramayu, merupakan bentuk kerja sama yang terjalin antara KBK Kewirausahaan, KBK Pemasaran, Fakultas Ekonomi di UK Maranatha dan GKP di Desa Tamiyang.

Desa Tamiyang merupakan desa yang terletak di Kecamatan Kroya Kabupaten Indramayu. Nama Tamiyang itu sendiri memiliki arti sebagai simbol pelindung dan lambing perputaran kehidupan. Asal mula munculnya Desa Tamiyang adalah ketika serombongan masyarakat dari Kawasan Tegal dan Brebes di jaman kolonial Belanda hendak bermigrasi ke Haurgeulis dengan menggunakan kereta api. Tetapi di tengah perjalanan, mereka di tahan oleh pemerintah Belanda di sekitar stasiun Cilegeh, sehingga mereka terpaksa turun tidak sampai tujuan dan menetap di Desa Tamiyang. Sehingga mayoritas Masyarakat Tamiyang ini pendahulu atau leluhurnya berasal dari kawasan Tegal dan Brebes, sehingga bahasa sehari-hari yang digunakan adalah bahasa Jawa dengan logat Tegal dan Brebes. Mayoritas mata pencaharian Masyarkat Tamiyang bergerak di bidang pertanian dan perkebunan, oleh karena didukung oleh alam yang menunjang. Namun di samping itu juga ada beberapa masyarakat yang bekerja sebagai pedagang warung. Permasalahan yang dihadapi oleh Masyarakat Tamiyang adalah hasil perkebunan yang melimpah terutama mangga terkadang banyak yang terbuang selain itu juga di Tamiyang itu sendiri belum ada produk yang menjadi ciri khas daerah tersebut. Di samping itu, terdapat juga permasalahan bahwa mereka pernah diajak bekerjasama oleh suatu perusahaan untuk memproduksi peti mati dari kayu dan dijanjikan akan dibantu dalam hal pemasarannya. Namun kemudian, mereka hilang kontak dengan perusahaan tersebut, sehingga produk peti mati yang telah dibuat tidak jadi dipasarkan oleh karena Masyarakat 
Tamiyang tidak paham mengenai pemasarannya. Selain itu juga untuk desain produk peti matinya itu sendiri masih banyak terdapat kekuarangan terutama mengenai presisi dan juga estetikanya.

Desa Tamiyang merupakan salah satu desa penghasil mangga terbaik di Indonesia, selain itu juga terdapat banyak bahan baku kayu yang dapat dihasilkan. Terkait dengan dua hal itulah maka, dalam kegiatan pengabdian masyarakat kali ini. Para Dosen dan Mahasiswa KBK Kewirausahaan dan KBK Pemasaran membantu optimalisasi potensi kewirausahaan dan pemasaran berdasarkan bahan baku yang terdapat di Desa Tamiyang. Terkait dengan bahan baku mangga, kami mengusulkan pembuatan usaha manisan mangga dan terkait dengan bahan baku kayu, kami mencoba melakukan tindaklanjut dan pendampingan dari produk peti mati yang sebelumnya sudah pernah dibuat oleh masyarakat Tamiyang.

\section{METODE PELAKSANAAN PKM}

Pelaksanaan kegiatan pengabdian masyarakat dilakukan dalam metode Focus Group Discussion (FGD) dan pelatihan. FGD adalah teknik di mana seorang peneliti mengumpulkan sekelompok individu untuk membahas topik tertentu, yang bertujuan untuk menarik dari pengalaman pribadi yang kompleks, keyakinan, persepsi dan sikap peserta melalui interaksi yang dimoderasi (Simspon \& Wood, 2004 dalam Nyumba, dkk. 2018). Selain itu Mishra (2016) menjelaskan bahwa FGD adalah jenis wawancara mendalam yang dilakukan dalam kelompok, yang pertemuannya menyajikan karakteristik yang ditentukan sehubungan dengan proposal, ukuran, komposisi, dan prosedur wawancara. Boateng (2012) menjelaskan bahwa FGD FGD menguntungkan karena menggunakan interaksi sosial yang lebih baik dalam menghasilkan data.

Dalam FGD yang dilakukan dalam kegiatan pengabdian masyarakat ini, terdapat beberapa tahapan yang dilakukan. Tahapan tersebut dapat dilihat pada Gambar 1.

Pada Gambar 1 dapat dilihat bahwa dalam FGD yang kami lakukan, terdapat beberapa tahapan mulai dari persiapan, pelaksanaan dan sesudah pelaksanaan. Pada tahap persiapan, kami menetapkan desain riset yang terdiri dari penetapan tujuan FGD. Adapun tujuan FGD yang kami lakukan dalam pengabdian masyarakat ini adalah pembahasan mengenai tindak lanjut tentang strategi dan implementasi pemasaran produk peti mati yang sebelumnya pernah dibuat oleh Masyarakat Tamiyang, namun belum optimal dalam pelaksanaannya. Dari tujuan tersebut kemudian disusun beberapa pertanyaan yang terkait dengan informasi yang ingin didapatkan. Adapun pertanyaan terkait dengan awal mula pembuatan peti mati, secara khusus alasan dibalik pembuatan produk peti mati ini, siapa saja pihak yang terlibat dalam pembuatannya dan apakah memang sudah ada pasar potensial yang ditargetkan, beberapa hal yang menjadi kendala sampai akhirnya pembuatan produk peti mati ini menjadi terhenti produksi dan pemasarannya, serta tentang bagaimana sebaiknya harga produk peti mati ditetapkan. Setelah itu kami juga melakukan identifikasi dan mengundang partisipan mana saja yang relevan untuk diajak melakukan FGD, serta memilih lokasi yang representatif untuk mendukung pelaksanaan FGD berjalan dengan baik. Pada tahap pelaksanaan, kami melakukan pengumpulan data yang terdiri dari kegiatan persiapan pra FGD berupa pemahaman pertanyaan diskusi, pemahaman mengenai dinamika kelompok, penempatan tempat duduk, dan peralatan yang dapat mendukung proses FGD berjalan dengan baik. Setelah itu kami melakukan FGD yang dimulai dari tahap perkenalan dari masing-masing pihak yang terlibat dalam proses diskusinya, kemudian dilanjutkan dengan proses diskusi dengan panduan dari beberapa pertanyaan-pertanyaan yang telah disiapkan sebelumnya, apabila ada informasi yang perlu diperjelas dapat mengajukan pertanyaan lanjutan, di akhir diskusi dilakukan kesimpulan dari proses FGD yang telah dilakukan. Setelah dilakukan FGD, kemudian dilakukan analisis terhadap percakapan yang telah dilakukan dalam proses FGD, yang pada akhirnya 
didapatkan keputusan atau tindaklanjut untuk akademisi, pengambil kebijakan dan praktisi, dan partisipan.

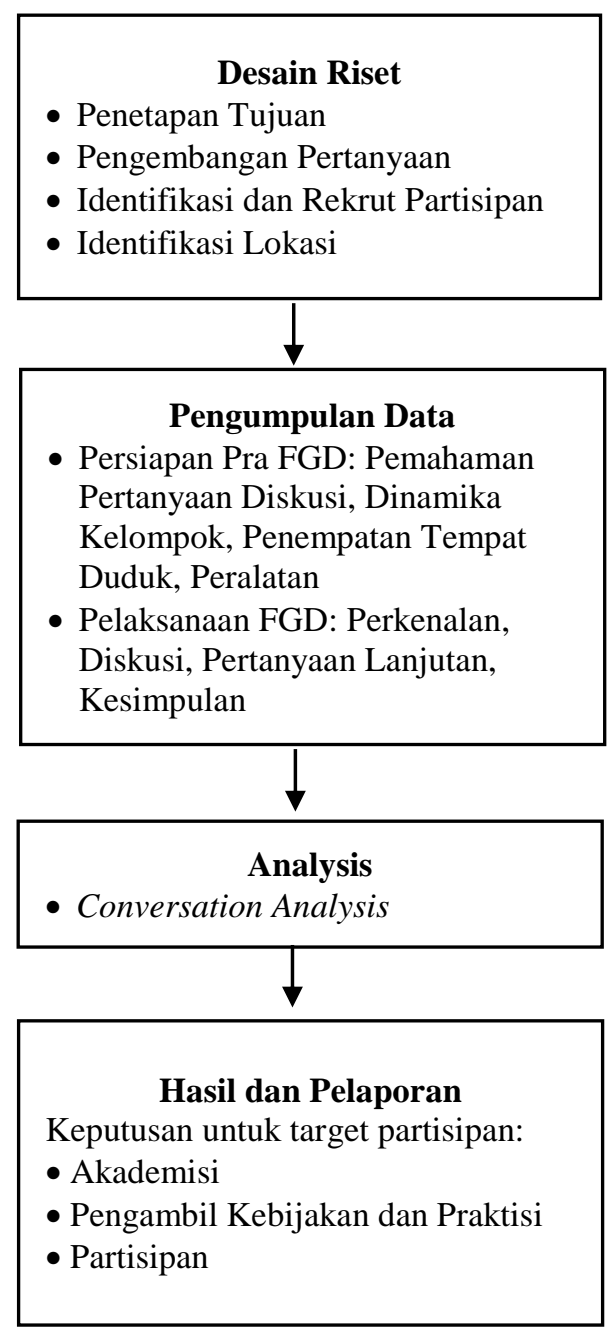

\section{Gambar 1. Alur Tahapan Focus Group Discussion}

Dalam kegiatan pengabdian masyarakat ini kami juga mengadakan pelatihan. Pelatihan mengacu pada proses memperoleh atau mentransfer pengetahuan, keterampilan dan kemampuan yang diperlukan untuk melaksanakan kegiatan atau fungsi tertentu. Pelatihan didefinisikan sebagai "proses yang direncanakan untuk mengubah sikap, pengetahuan, keterampilan atau perilaku melalui pengalaman belajar untuk mencapai kinerja yang efektif dalam suatu kegiatan atau berbagai kegiatan (Wilhem, 2014). Vinesh (2014) menambahkan bahwa pelatihan diperlukan untuk meningkatkan keterampilan, teknik, dan pengetahuan yang terkait dengan pekerjaan. Martin, dkk (2014) menjelaskan bahwa learning modality atau metode pelatihan yang dapat dilakukan terdiri dari tiga jenis yaitu: learning by doing, learning by seeing, dan learning by hearing. Learning by doing mengacu pada situasi di mana peserta pelatihan memperoleh konten pelatihan melalui tindakan melakukan tugas. Learning by doing sejalan dengan filosofi pendidikan yang disebut sebagai experiential education, yang menegaskan bahwa belajar datang melalui transformasi pengalaman. Learning by seeing merujuk pada kasus-kasus di mana peserta pelatihan memperoleh konten pelatihan dengan melihat tugas yang dilakukan, dan learning by hearing merujuk pada perolehan konten pelatihan dengan mendengar. Dalam kegiatan pengabdian masyarakat ini, pelatihan yang dilakukan adalah dengan learning by doing, dimana peserta diajak 
langsung melakukan apa yang telah diajarkan bersama-sama dengan kami. Dengan fokus pelatihan terkait dengan tindak lanjut tentang proses pembuatan manisan mangga, selain itu kami juga membuat video promosi yang bertujuan untuk menyebarluaskan manisan mangga yang akan menjadi ciri khas Tamiyang.

\section{HASIL DAN PEMBAHASAN}

Kegiatan pengabdian masyarakat dilakukan pada tanggal 29 dan 30 November 2019. Pada 29 November 2019, kami terlebih dahulu melakukan diskusi awal mengenai perkembangan terakhir dari implementasi hasil dari kegiatan pengabdian masyarakat sebelumnya. Beberapa hasil diskusi yang didapat adalah pemberian informasi mengenai usulan dari Para Dosen Kewirausahaan dan Pemasaran mengenai luaran produk yang akan menjadi ciri khas Desa Tamiyang, selain itu juga terdapat kesepakatan mengenai usulan produk keunggulan Tamiyang tersebut. Hal ini tentu saja memberikan perkembangan atau kemajuan dari Desa Tamiyang, karena selama ini memang belum ada produk yang menjadi ciri has dari Desa Tamiyang. Usulan produk yang menjadi keunggulan Tamiyang adalah berupa manisan mangga. Selain itu terdapat juga diskusi awal mengenai strategi dan implementasi pemasaran produk peti mati. Produk peti mati ini sebelumnya sudah pernah dibuat oleh Masyarakat Tamiyang, namun karena tidak ada pendampingan oleh perusahaan yang pernah bekerjasama menjadi terbengkalai. Pasar produk peti mati ini sebenarnya sangat besar karena di daerah Tamiyang sendiri belum ada yang memproduksi peti mati, sehingga terkadang masyarakat Tamiyang membelinya di Indramayu yang jaraknya sekitar kurang lebih 2 jam. Selain itu juga terdapat tempat ibadah di Cirebon yang merupakan rekanan dari Koperasi Tamiyang memiliki keinginan untuk membeli. Gambar 2 adalah dokumentasi diskusi awal pada tanggal 29 November 2019 dalam kegiatan pengabdian masyarakat di Desa Tamiyang.

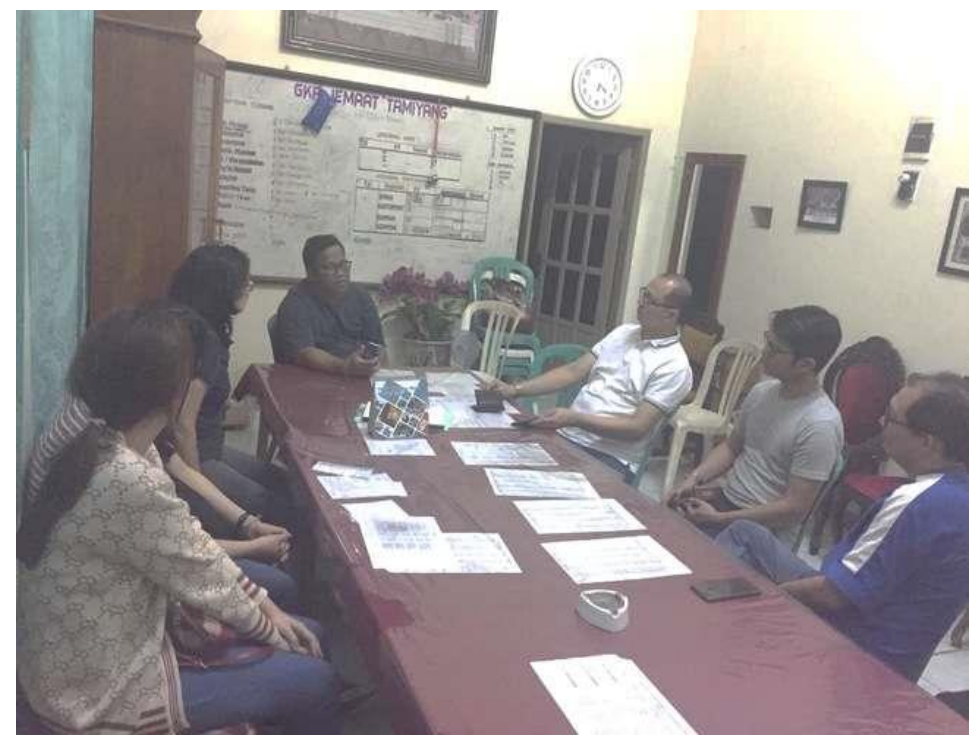

Gambar 2. Diskusi Awal Potensi Kewirausahaan dan Pemasaran Produk Tamiyang

Pada keesokan harinya, tanggal 30 November 2019. Kegiatan pengabdian masyarakat yang dilakukan adalah FGD dan pelatihan tentang optimalisasi potensi kewirausahaan dan pemasaran produk Tamiyang. Dalam kegiatan pengabdian masyarakat pada hari kedua, pelaksanaannya dibagi menjadi dua bagian. Pada bagian satu dilakukan FGD tentang optimalisasi potensi kewirausahaan dan pemasaran produk peti mati. Adapun FGD terkait dengan produk peti mati Tamiyang, adalah seputar perhitungan harga pokok penjualan sebagai dasar dari sebuah penetapan harga dari peti mati tersebut. Hal ini sangat penting dilakukan oleh karena, masyarakat Tamiyang 
masih belum mengetahui berapa harga peti mati yang akan ditawarkan ke pasar. Hal ini mengingat pada waktu pertama kali pembuatan peti mati, bahan baku yang dibutuhkan berasal dari perusahaan yang dulu mendampingi mereka. Sehingga untuk harga bahan baku yang diperlukan untuk pembuatan peti mati tidak diketahui dengan jelas. Selain itu juga dihasilkan kesepakatan mengenai akan diadakannya pelatihan mengenai pembuatan desain peti mati yang dapat menyebabkan peti mati tersebut tampak lebih baik secara penampilan atau desainnya. Terkait dengan hal ini, akan ditindaklanjuti pada pengabdian masyarakat di semester berikutnya dengan adanya tenaga bantuan dari Para Dosen dan Mahasiswa Desain Interior Fakultas Seni Rupa dan Desain Maranatha. Kegiatan FGD dalam kegiatan pengabdian masyarakat Tamiyang dapat dilihat pada Gambar 3.

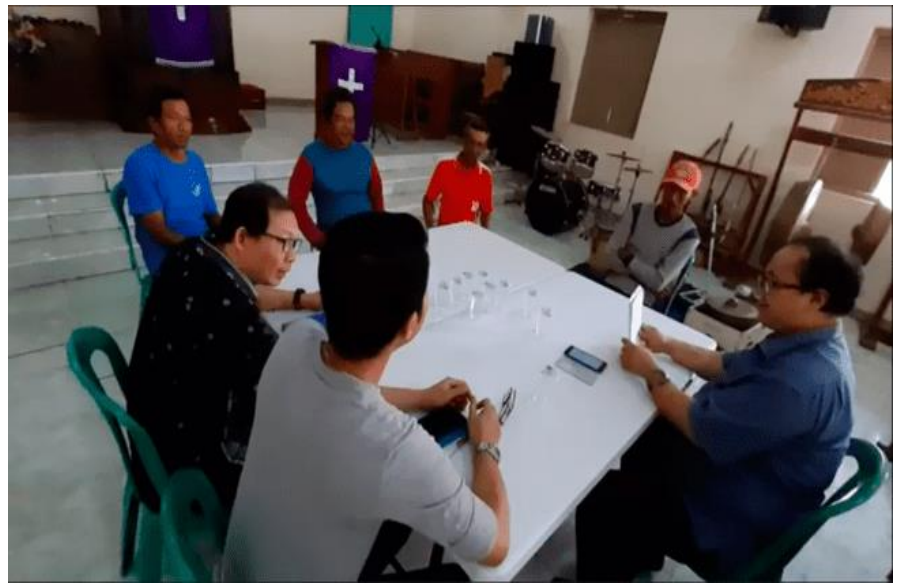

Gambar 3. Focus Group Discussion Potensi Kewirausahaan dan Pemasaran Produk Peti Mati Tamiyang

Untuk proses pembuatan peti mati dan juga produk peti mati yang telah dibuat oleh Masyarakat Tamiyang, dapat dilihat pada Gambar 4.

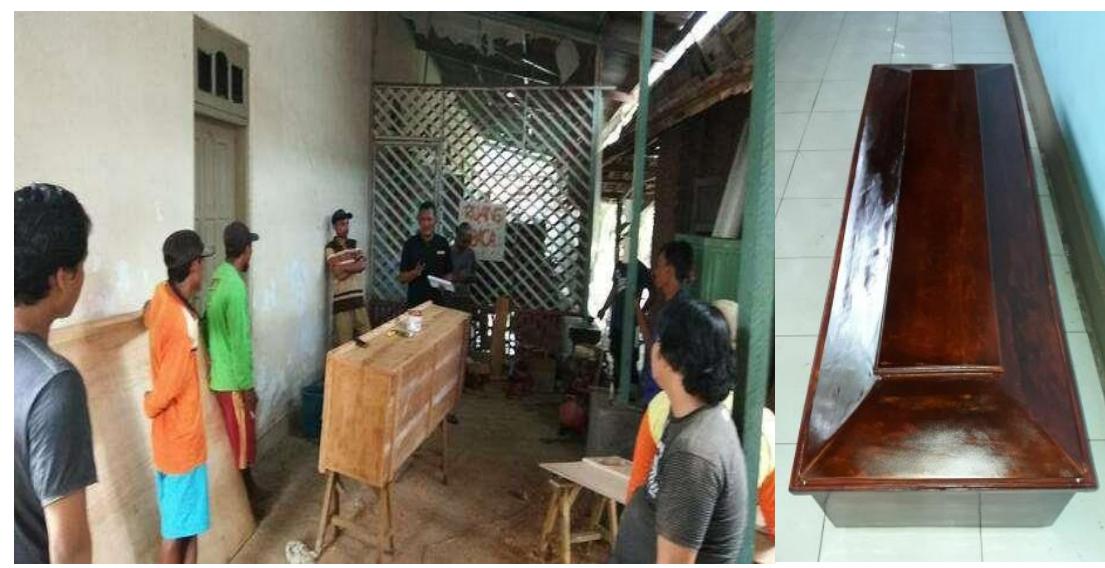

Gambar 4. Proses Pembuatan dan Produk Peti Mati

Pada bagian lainnya dalam kegiatan pengabdian masyarakat Tamiyang, diadakan pelatihan pembuatan manisan mangga. Adapun nama yang ditaawarkan oleh Para Dosen KBK Kewirausahaan dan KBK Pemasaran adalah Manisan Si Mayang. Kata "Mayang" memiliki arti Mangga Tamiyang. Dan produk ini memiliki tagline "Bikin Anda Makin DiSayang". Penamaan merek dan tagline ini menyesuaikan dengan kebiasan yang terdapat di daerah pantura, selain agar mudah diingat karena memiliki ciri khas dalam penamaannya. Pelatihan pembuatan manisan ini 
mulai dari penyiapan bahan baku yang diperlukan: mangga, gula, garam, cabai, dan cuka kemudian dilanjutkan pada proses pembuatan dan diakhiri dengan proses pengemasan.

Adapun alur proses pembuatannya dapat dilihat pada Gambar 5.

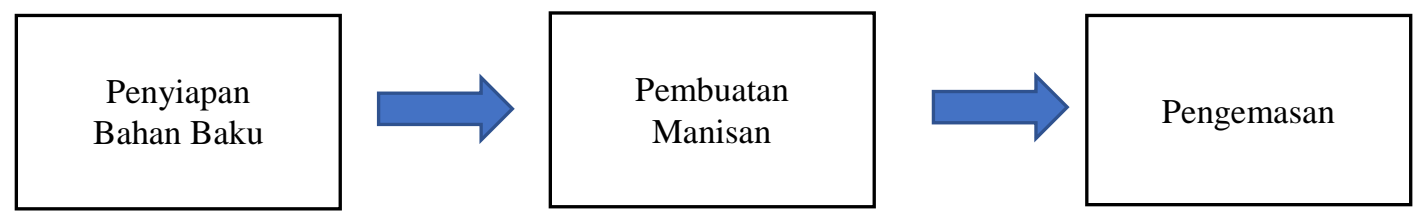

Gambar 5. Alur Pembuatan Manisan Si Mayang

Dokumentasi terkait pelatihan pembuatan manisan mangga dapat dilihat pada Gambar 6.

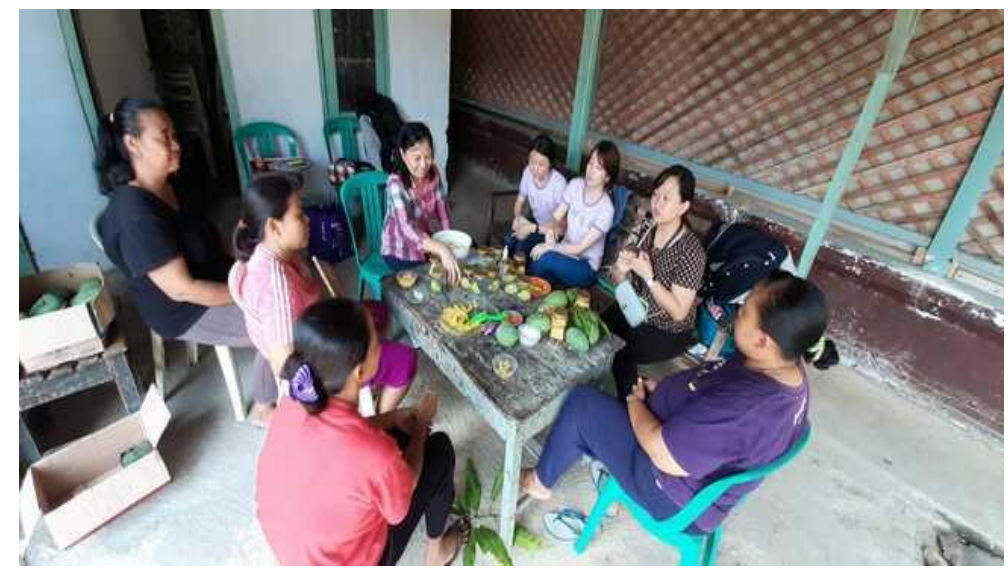

Gambar 6. Pelatihan Pembuatan Manisan Si Mayang

Setelah proses pembuatan manisan mangga ini selesai dilakukan, maka akan didapati produk Manisan Si Mayang yang dapat dilihat pada Gambar 7.

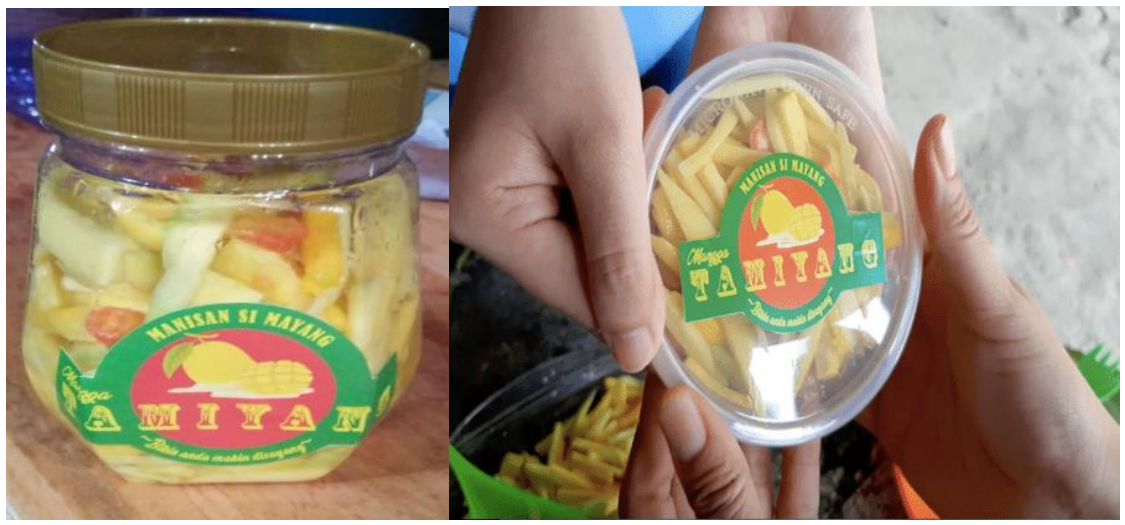

Gambar 7. Produk Manisan Si Mayang

Pada pengabdian masyarakat ini kami juga membuat video tutorial proses pembuatan Manisan Si Mayang beserta video promosinya. Pembuatan video tutorial proses pembuatan ini bertujuan agar masyarakat Tamiyang dapat berlatih secara mandiri tanpa pendampingan dari kami dalam melakukan eksperimen mengenai pembuatan racikan manisan mangga. Selain itu video promosi tentang Manisan Si Mayang bertujuan agar manisan ini dapat dikenal luas oleh masyarakat 
lainnya, sehingga diharapkan dapat meningkatkan potensi penjualan dari manisan mangga ini. Adapun link dari video tutorial dan promosi tersebut adalah:

https://drive.google.com/file/d/1r70mDvqw31DbvasXgQ04a7bHlXYn79qO/view?usp=drivesdk

Gambar 8 merupakan salah satu klip yang terdapat dalam video tutorial dan promosi Manisan Si Mayang.

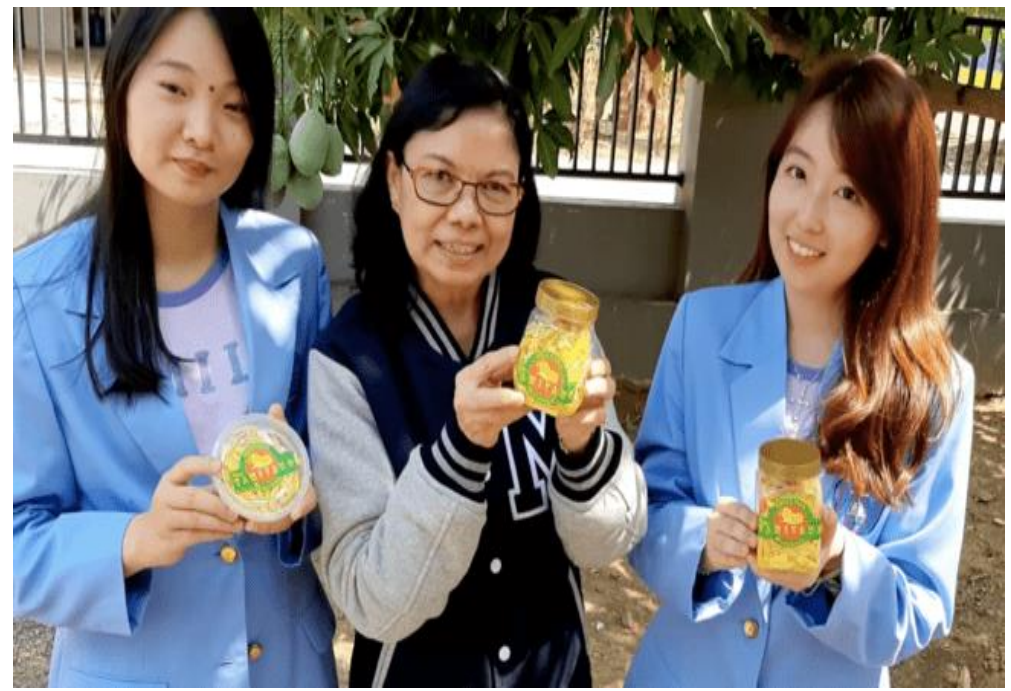

Gambar 8. Klip Video Tutorial dan Promosi Manisan Si Mayang

\section{KESIMPULAN DAN SARAN}

Tamiyang merupakan desa yang memiliki hasil pertanian dan perkebunan yang melimpah, salah satu hasil perkebunan yang dihasilkan adalah mangga. Selain itu juga banyak sekali bahan baku yang tersedia di desa tersebut. Kedua sumber bahan baku yang tersedia di alam, baik itu mangga dan kayu belum dimanfaatkan secara optimal untuk menambah nilai, khususnya untuk meningkatkan perekonomian masyarakat. Kegiatan pengabdian masyarakat di Desa Tamiyang menghasilkan beberapa hal. Tindaklanjut dalam optimalisasi potensi kewirausahaan dan pemasaran produk peti mati, khususnya mengenai penetapan harga produk berdasarkan pada harga pokok penjualan yang diperoleh dari proses diskusi, selain itu juga dibutuhkan adanya kegiatan pelatihan tentang desain produk agar peti mati yang dihasilkan memiliki unsur keindahan juga disamping kegunaan fungsinya. Kegiatan ini juga menghasilkan pengetahuan untuk masyarakat Tamiyang tentang pembuatan manisan mangga Si Mayang, yang diperoleh dari pelatihan proses pembuatannya. Selain itu juga terdapat video yang berisi mengenai tutorial dan promosi tentang produk Manisan Si Mayang, yang harapannya dapat meningkatkan kemandirian dari masyarakat Tamiyang dalam hal pembuatan produk manisan serta agar produk manisan ini dapat dikenal secara luas di seluruh Indonesia. Kegiatan pengabdian masyarakat ini masih terus perlu dilakukan secara berkesinambungan agar didapati hasil yang optimal terkait potensi kewirausahaan dan pemasaran produk unggulan Tamiyang.

\section{Ucapan Terima Kasih (Acknowledgement)}

Dalam kegiatan ini, kami mengucapkan terimakasih kepada Lembaga Penelitian dan Pengabdian Masyarakat dan Fakultas Ekonomi Universitas Kristen Maranatha yang telah membantu dalam hal dukungan baik materiil maupun non-materiil, sehingga acara kegiatan pengabdian masyarakat ini dapat berjalan dengan baik. Kami juga mengucapkan terimakasih kepada Gereja Kristen Pasundan 
Rehoboth Tamiyang yang telah menjadi fasilitator antara Universitas Kristen Maranatha dan Masyarakat Tamiyang.

\section{REFERENSI}

Boateng, W. (2012). Evaluating the Efficacy of Focus Group Discussion (FGD) in Qualitative Social Research. International Journal of Business and Social Science. 3 (7), 54-57.

Martin, B.O., Kolomitro, M., Lam, T.C.M. (2014). Training Methods: A Review and Analysis. Human Resource Development Review. 13 (1), 11-35.

Mishra, L. (2016). Focus Group Discussion in Qualitative Research. TechnoLEARN. 6 (1), 1-5.

Nyumba, T. O., Wilson, K., Derrick, C.J., Mukherjee, N. (2018). The Use of Focus Group Discussion Methodology: Insights from Two Decades of Application in Conversation. Methods in Ecology and Evolution. 9, 20-32.

Undang-Undang No. 12 Tahun 2012 Tentang Pendidikan Tinggi

Vinesh. (2014). Role of Training \& Development in an Organizational Development. International Journal of Management and International Business Studies. 4 (2), 213-220.

Wilhem, W., Abushamsieh, K., Arostegui, M. N. P. (2014). Training Strategies, Theories and Types. Journal of Accounting - Business \& Management. 21 (1), 12-26. 